\title{
ANALISIS FAKTOR-FAKTOR YANG MEMPENGARUHI MINAT WAJIB PAJAK ORANG PRIBADI DALAM MENGGUNAKAN E-FILING SEBAGAI SARANA PELAPORAN SPT PADA KPP PRATAMA POSO
}

\author{
Sofyarifani Pu'o ${ }^{1}$, Jullie J. Sondakh ${ }^{2}$, Novi S. Budiarso ${ }^{3}$ \\ 1,2,3 Jurusan Akuntansi, Fakultas Ekonomi dan Bisnis, Universitas Sam Ratulangi, Jl. Kampus Bahu, Manado, \\ 95115, Indonesia \\ E-mail : sofyarifani.puo@gmail.com
}

\begin{abstract}
The purpose of this research is to examine the factors affecting interests of taxpayers in using e-Filing facility. The dependent variable used in this research is the interest of tax payers, while the independent variables are perceived usefulness, perceived ease of use, security and privacy, complexity, and readiness technology taxpayers information. The respondents are individual taxpayers who used e-Filing that are listed in Poso, Tax Office. This research used multiple linear regression analysis that involved 100 respondents. The results show that: (1) perceived usefulness affects positively the intention to use e-Filing, (2) perceived ease of use affects positively the intention to use e-Filing, (3) security and privacy affects positively the intention to use e-Filing, (4) complexity affects negatively the intention to use e-Filing, (5) readiness technology taxpayers information affects positively the intention to use e-Filing.

Keywords: Perceived Usefulness, Perceived Ease Of Use, Security and Privacy, Complexity, Readiness Technology Taxpayers Information, e-Filing.
\end{abstract}

\section{PENDAHULUAN}

Pajak merupakan pendapatan negara yang paling besar. Penerimaan pajak berasal dari iuran yang harus dibayar oleh rakyat sebagai konsekuensi berlakunya undang-undang. Wajib pajak tidak mendapat imbalan langsung dari iuran yang dibayarkan. Sehingga wajib pajak tidak mau untuk membayar pajak. Seperti yang dikatakan oleh Sakti (2015:2) bahwa setiap orang enggan untuk membayar pajak, salah satu penyebabnya adalah karena tidak adanya kontrapretasi atau imbalan secara langsung yang diterima ketika seseorang membayar pajak. Padahal pajak bertujuan meningkatkan kesejahteraan masyarakat dalam bentuk peningkatan maupun perbaikan sarana publik.

Di era globalisasi ini, banyak perubahan dalam aspek kehidupan. Sebagai contoh perkembangan teknologi yang dari tahun ke tahun mengalami perkembangan pesat. Pengaruh kemajuan teknologi membawa kemudahan dalam melakukan tugas-tugas kearsipan. Kelebihan utama dalam arsip elektronik tentu lebih praktis dan memiliki resiko yang lebih kecil. Mengantisipasi perkembangan informasi dan teknologi tersebut, berbagai terobosan yang terkait dengan teknologi informasi dalam kegiatan perpajakan pun terus dilakukan, dengan tujuan untuk memudahkan dan mengoptimalkan pelayanan kepada wajib pajak. $E$ Filing adalah suatu layanan pengiriman atau penyampaian SPT secara elektronik bagi wajib pajak orang pribadi maupun badan (perusahaan, organisasi) ke DJP. E-Filing dilakukan dengan memanfaatkan jalur internet secara online dan real time, sehingga wajib pajak tidak perlu lagi melakukan pencetakan semua formulir laporan dan menunggu tanda terima secara manual (Laihad, 2013:45). Namun saat ini, mayoritas wajib pajak belum menerapkan $e$ Filing. Hal tersebut disebabkan karena kurangnya sosialisasi dari DJP dan rendahnya pengetahuan wajib pajak mengenai teknologi baru (internet) untuk melaporkan pajaknya. 
E-Filing menawarkan banyak manfaat kepada penggunanya, seperti kemudahan dalam pelaporan karena dengan menggunakan e-Filing, pelaporan SPT dapat dilakukan dalam waktu 24 jam melalui jaringan internet yang memiliki proses online dan real time, selain itu pengguna $e$-Filing juga dapat memonitoring akan proses kemajuan secara real time dari pelaporan pajak yang telah dikirimkan. Mengurangi kemungkinan kesalahan penginputan data karena software secara otomatis dapat memeriksa apakah terjadi kesalahan dalam penginputan data. Selain itu e-Filing juga memberikan keamanan yang tinggi pada data pengguna. Karena sistem e-Filing dilindungi secara khusus sehingga hanya sistem computer Direktorat Jenderal Pajak yang dapat mengakses data tersebut.

Dari manfaat-manfaat ini, salah satu faktor yang mempengaruhi minat pengguna $e$ Filing sehingga terjadi jumlah peningkatan pengguna adalah adanya faktor persepsi kegunaan (perceived usefulness). Persepsi kegunaan diyakini oleh individu adalah manfaat yang akan dapat diperoleh apabila menggunakan suatu teknologi informasi, salah satunya e-Filing. Adapun beberapa faktor yang dinilai akan sangat berpengaruh seperti halnya dalam penelitian Tania (2016) yang mengatakan bahwa persepsi kemudahan (perceived ease of use) mempengaruhi minat menggunakan e-Filing karena dapat di gunakan dengan mudah dan dapat dipahami dengan mudah. Faktor lain yang mempengaruhi minat pengguna $e$-Filing adalah keamanan dan kerahasiaan (security and privacy).

Setelah menerima manfaat, kemudahan, serta keamanan dan kerahasiaan dalam menggunakan $e$-Filing yang dapat memicu minat wajib pajak dalam menggunakannya, faktor lain yang dapat mempengaruhi minat wajib pajak dalam menggunakan e-Filing adalah kerumitan (complexity). Hal ini didukung penelitian Ekamaulana (2016) yang menyebutkan dalam penelitiannya bahwa kerumitan tidak berpengaruh negatif terhadap minat dalam penggunaan e-Filing. Hasil inilah yang menjadi dasar peneliti memilih variabel kerumitan. Wibisono dan Toly (2014) menunjukkan bahwa kesiapan teknologi pada dasarnya dipengaruhi oleh individu itu sendiri, apakah dari dalam diri individu siap menerima teknologi khususnya dalam hal ini e-Filing. Dari beberapa penelitian di atas, peneliti menambahkan variabel independen berupa keamanan dan kerahasiaan (security and privacy), kerumitan (complexity), dan kesiapan teknologi informasi wajib pajak (readiness technology taxpayers information). Keenam faktor tersebut diharapkan dapat memberi dampak positif dalam peningkatan minat wajib pajak dalam menggunakan $e$-Filing sebagai sarana pelaporan SPT secara online dan real time. Adapun tujuan yang ingin dicapai dalam penelitian ini adalah:

1. Untuk mengetahui pengaruh persepsi kegunaan terhadap minat wajib pajak dalam menggunakan e-Filing.

2. Untuk mengetahui pengaruh persepsi kemudahan terhadap minat wajib pajak dalam menggunakan $e$-Filing.

3. Untuk mengetahui pengaruh keamanan dan kerahasiaan terhadap minat wajib pajak dalam menggunakan $e$-Filing.

4. Untuk mengetahui pengaruh kerumitan terhadap minat wajib pajak dalam menggunakan $e$-Filing.

5. Untuk mengetahui pengaruh kesiapan teknologi informasi terhadap minat wajib pajak dalam menggunakan $e$-Filing.

6. Untuk mengetahui pengaruh persepsi kegunaan, persepsi kemudahan, keamanan dan kerahasiaan, kerumitan dan kesiapan teknologi informasi terhadap minat wajib pajak dalam menggunakan $e$-Filing. 


\section{TINJAUAN PUSTAKA}

\subsection{E-Filing}

E-Filing merupakan cara penyampaian Surat Pemberitahuan (SPT) Tahunan atau Pemberitahuan Perpanjangan yang dilakukan secara online yang real time melalui Penyedia Jasa Aplikasi atau Application Service Provider (ASP). Sedangkan aplikasi elektronik SPT (e-SPT) adalah suatu aplikasi untuk digunakan oleh wajib pajak yang dibuat oleh Direktorat Jenderal Pajak untuk kemudahan dalam penyampaian SPT (www.pajak.go.id). Dengan pengertian tersebut, $e$-Filing adalah cara penyampaian SPT sedangkan $e$-SPT adalah media penyampaiannya (formulir).

\subsection{Technology Acceptance Model (TAM)}

Davis (1989) menyusun suatu model untuk menjelaskan penerimaan teknologi yang akan digunakan oleh pengguna teknologi yang disebut Technology Acceptance Model (TAM). Davis (1989) memberikan penjelasan bahwa perilaku individu dalam menggunakan Teknologi Informasi dimulai dari persepsi kegunaan (usefulness) dan persepsi kemudahan dalam menggunakan Teknologi Informasi (ease of use). Davis mendefinisikan useful yaitu dari capable of being used advantageously, atau dengan kata lain bisa digunakan untuk tujuan yang menguntungkan. Kemudahan (ease) bermakna tanpa kesulitan atau juga terbebaskan dari kesulitan, tidak perlu berusaha keras.

\subsection{Pengaruh Persepsi Kegunaan (Perceived Usefulness) Terhadap Minat Wajib Pajak Dalam Menggunakan $\boldsymbol{e}$-Filing.}

Menurut Davis (1989) Persepsi kegunaan pada Teori Technology Acceptance Model (TAM) merupakan faktor yang paling dominan dalam mempengaruhi pengguna menentukan sikap dalam penggunaan suatu sistem, atau dapat diartikan menentukan individu berniat atau tidak menggunakan sistem e-Filing. Persepsi kegunaan merupakan suatu manfaat yang diharapkan oleh wajib pajak mengenai aktivitas pengisian SPT Tahunan secara online. Wajib pajak yang sebelumnya biasa mengisi SPT secara manual, kini dapat mengisi SPT secara online yang dapat memberikan banyak manfaat untuk wajib pajak. Sehingga, ketika wajib pajak menganggap bahwa $e$-Filing memberikan manfaat, maka wajib pajak akan berminat untuk menggunakan $e$-Filing. Berdasarkan beberapa studi yang telah diuraikan diatas, maka peneliti merumuskan hipotesis penelitian sebagai berikut :

H1 : Persepsi Kegunaan (Perceived Usefulness) berpengaruh positif terhadap Minat Wajib Pajak Orang Pribadi dalam Menggunakan e-Filing.

\subsection{Pengaruh Persepsi Kemudahan (Perceived Ease Of Use) Terhadap Minat Wajib Pajak Dalam Menggunakan $e$-Filing.}

Indikator untuk persepsi kemudahan tentang kegunaan sistem teknologi menurut Venkatesh dan Davis (2000:201) yaitu :

a) Interaksi individu dengan sistem jelas dan mudah dimengerti

b) Interaksi dengan sistem tidak membutuhkan banyak usaha

c) Sistem mudah digunakan dan sesuai dengan kebutuhan dalam mengerjakan pekerjaan individu.

Persepsi kemudahan merupakan salah satu variabel yang banyak digunakan untuk mengetahui pengaruh terhadap minat pengguna teknologi dalam mengunakannya. Kemudahan-kemudahan yang ditawarkan dari sistem e-Filing seperti kemudahan dalam mengakses, kemudahan dalam mengisinya akan memicu wajib pajak untuk menggunakan $e$ Filing. Secara lebih lanjut, semakin tinggi kemudahan yang didapatkan oleh wajib pajak, maka semakin tinggi pula minat untuk menggunakan $e$-Filing.

Berdasarkan beberapa studi yang telah diuraikan diatas, maka peneliti merumuskan hipotesis penelitian sebagai berikut:

$\mathrm{H} 2$ : Persepsi Kemudahan (Perceived Ease Of Use) berpengaruh positif terhadap Minat Wajib Pajak Orang Pribadi dalam Menggunakan $e$-Filing. 


\subsection{Pengaruh Keamanan Dan Kerahasiaan (Security And Privacy) Terhadap Minat Wajib Pajak Dalam Menggunakan e-Filing.}

Teori Task Technology Fit (TTF) menjadi dasar hipotesis ketiga mengenai keamanan dan kerahasiaan pada intensitas penggunaan e-Filing. Goodhue dan Thompson (1995) menyatakan bahwa jika teknologi (sistem e-Filing) dirasakan memberikan manfaat positif bagi para penggunanya, maka dapat diartikan bahwa keamanan dan kerahasiaan merupakan aspek positif yang ada di dalam sistem e-Filing yang mempengaruhi perilaku wajib pajak sebagai pengguna dalam penggunan secara berkelanjutan. Wajib Pajak yang sudah paham akan keamanan dan kerahasiaan sistem $e$-Filing tersebut tentunya mereka akan menggunakan $e$-Filing atau dengan kata lain keamanan dan kerahasiaan mempunyai pengaruh yang positif terhadap minat wajib pajak dalam penggunaan $e$-Filing.

Berdasarkan beberapa studi yang telah diuraikan diatas, maka peneliti merumuskan hipotesis penelitian sebagai berikut:

H3 : Keamanan Dan Kerahasiaan (Security And Privacy) berpengaruh positif terhadap Minat Wajib Pajak Orang Pribadi dalam Menggunakan e-Filing.

\subsection{Pengaruh Kerumitan (Complexity) Terhadap Minat Wajib Pajak Dalam Menggunakan e-Filing.}

Menurut Amoroso dan Gardner (2004), TAM menambahkan konstruk eksternal yaitu kerumitan (complexity), dapat diartikan bahwa semakin kompleks suatu inovasi, maka akan semakin rendah pula tingkat pengaplikasiannya. Inovasi terhadap sebuah teknologi bisa mempengaruhi pemahaman pengguna untuk menggunakan teknologi tersebut. Kerumitan akan muncul, jika wajib pajak belum bisa menerima sebuah teknologi baru dalam pelaporan pajaknya (e-Filing) dengan alasan sudah nyaman mengisi SPT secara manual dan belum terbiasa menggunakan $e$-Filing, selain itu mereka menginterpretasikan bahwa teknologi yang baru ini dapat menyita waktu dalam mempelajarinya, sehingga wajib pajak enggan untuk menggunakan $e$-Filing. Ketika subjek pajak atau wajib pajak mempersepsikan bahwa $e$ Filing itu merupakan sesuatu yang rumit, maka mereka cenderung untuk tidak menggunakan $e$-Filing. Dengan kata lain Kerumitan mempunyai pengaruh yang negatif terhadap minat perilaku dalam penggunaan $e$-Filing.

Berdasarkan beberapa studi yang telah diuraikan diatas, maka peneliti merumuskan hipotesis penelitian sebagai berikut:

H4 : Kerumitan (Complexity) berpengaruh negatif terhadap Minat Wajib Pajak Orang Pribadi dalam Menggunakan e-Filing.

\subsection{Pengaruh Kesiapan Teknologi Informasi Wajib Pajak (Readiness Technology} Taxpayers Information) Terhadap Minat Wajib Pajak Dalam Menggunakan $e$ Filing.

Menurut Ajzen (2005) Theory of Planned Behavior (TPB) ini memiliki faktor-faktor yang mempengaruhi minat pada penggunaan sistem. Salah satunya adalah faktor keyakinan perilaku. Kesiapan teknologi pada dasarnya dipengaruhi oleh individu itu sendiri, apakah individu tersebut siap atau tidak menerima teknologi khususnya dalam hal ini e-Filing. Kesiapan teknologi informasi juga mempengaruhi kemajuan pola pikir individu, artinya semakin individu siap menerima teknologi yang baru berarti semakin maju pemikiran individu tersebut yaitu bisa beradaptasi dengan teknologi yang semakin lama semakin berkembang ini.

Berdasarkan beberapa studi yang telah diuraikan diatas, maka peneliti merumuskan hipotesis penelitian sebagai berikut:

H5 : Kesiapan Teknologi Informasi Wajib Pajak (Readiness Technology Taxpayers Information) berpengaruh positif terhadap Minat Wajib Pajak Orang Pribadi dalam Menggunakan $e$-Filing. 


\subsection{Pengaruh Persepsi Kegunaan (Perceived Ease Of Use), Persepsi Kemudahan (Perceived Ease Of Use), Keamanan dan Kerahasiaan (Security And Privacy), Kerumitan (Complexity), Kesiapan Teknologi Informasi (Readiness Technology Taxpayers Information) Terhadap Minat Wajib Pajak Orang Pribadi Dalam Menggunakan $\boldsymbol{e}$-Filing.}

H6: Persepsi Kegunaan (Perceived Ease Of Use), Persepsi Kemudahan (Perceived Ease Of Use), Keamanan dan Kerahasiaan (Security And Privacy), Kerumitan (Complexity), Kesiapan Teknologi Informasi (Readiness Technology Taxpayers Information) berpengaruh signifikan terhadap Minat Wajib Pajak Orang Pribadi dalam Menggunakan $e$-Filing.

\section{METODE PENELITIAN}

\subsection{Jenis dan Sumber Data}

Penelitian ini menggunakan pendekatan kuantitatif. Metode yang digunakan dalam penelitian ini yaitu metode Penelitian asosiatif. Penelitian asosiatif merupakan penelitian yang bertujuan untuk mengetahui pengaruh atau hubungan antara dua variabel atau lebih (Sugiyono, 2016:36). Penelitian ini dilakukan untuk mengetahui hubungan antara variabel independen $(\mathrm{X})$ dan variabel dependen $(\mathrm{Y})$. Variabel independen terdiri dari 5 variabel yaitu persepsi kegunaan, persepsi kemudahan, keamanan dan kerahasiaan, kerumitan dan kesiapan teknologi informasi. Dan variabel dependen yaitu minat wajib pajak orang pribadi dalam menggunakan $e$-Filing. Sumber data yang digunakan dalam penelitian ini adalah data primer yang secara langsung bersumber dari responden tanpa ada perantara, dalam hal ini adalah jawaban atas pertanyaan dan pernyataan yang ada dalam kuesioner.

\subsection{Sampel dan Teknik Pengambilan Sampel}

Populasi penelitian ini yaitu wajib pajak orang pribadi yang terdaftar di Kantor Pelayanan Pajak (KPP) Pratama Poso. Wajib pajak orang pribadi yang terdaftar di KPP Pratama Poso pada tahun 2016 yaitu 51,977 dan yang telah melaporkan SPT menggunakan $e$ Filing sebanyak 22,436 wajib pajak. Sampel yang digunakan dalam penelitian ini yaitu Wajib Pajak Orang Pribadi di wilayah Kabupaten Poso yang telah menggunakan atau menerapkan sistem perpajakan $e$-Filing.

Teknik pengambilan sampel dalam penelitian ini menggunakan metode Purposive Sampling yaitu dengan menentukan indikator-indikator spesifik sehubungan data yang diperlukan, yang dimiliki oleh populasi yang telah ditentukan sebelumnya.

Kriteria sampel yang digunakan adalah sebagai berikut :

1. Wajab Pajak Orang Pribadi yang bertempat tinggal di Kabupaten Poso.

2. Sudah pernah menggunakan atau menerapkan sistem perpajakan e-Filing dalam pelaporan SPT.

Dalam penelitian ini peneliti juga menggunakan penentuan ukuran sampel statistik, yakni dengan menggunakan rumus Slovin sebagai formula penentuan ukuran sampelnya, sebagai berkut:

$\mathrm{n}=\frac{\mathrm{N}}{1+\mathrm{N} \cdot \mathrm{e}^{2}}$

Keterangan :

$$
\begin{aligned}
\mathrm{n} & =\text { ukuran sampel } \\
N & =\text { ukuran populasi } \\
e & =\text { batas eror yaitu } 10 \% .
\end{aligned}
$$


$\mathrm{n}=\frac{22.436}{1+22.436(0.1)^{2}}=\frac{22.436}{1+224.36}=\frac{22.436}{225.36}=99.55$

Jumlah sampel yang dibutuhkan tersebut dibulatkan menjadi 100 responden, kuesioner disebarkan mulai tanggal 11 Desember 2017 sampai dengan 25 Januari 2018. Berdasarkan teknik tersebut, peneliti membagikan kuesioner sebanyak 100 kuesioner.

\subsection{Metode Analisis}

Analisis data berisi pengujian data yang diperoleh dari hasil jawaban responden yang diterima, sehingga dapat disimpulkan apakah hipotesis diterima atau ditolak. Analisis data yang digunakan dalam penelitian ini adalah sebagai berikut, uji asumsi klasik yang terdiri dari uji normalitas, uji multikolinearitas, uji heteroskedastisitas, dan uji autokorelasi sebelum melakukan uji regresi dan uji hipotesis.

\section{HASIL ANALISIS DAN PEMBAHASAN}

\subsection{Hasil Analisis}

\subsubsection{Uji Kualitas Data}

\section{A. Uji Validitas}

Hasil pengujian validitas atas pertanyaan-pertanyaan dari variabel Persepsi Kegunaan $\left(\mathrm{X}_{1}\right)$, Persepsi Kemudahan $\left(\mathrm{X}_{2}\right)$, Keamanan dan Kerahasiaan $\left(\mathrm{X}_{3}\right)$, Kerumitan $\left(\mathrm{X}_{4}\right)$, Kesiapan Teknologi Informasi $\left(\mathrm{X}_{5}\right)$ dan Minat Wajib Pajak Orang Pribadi Dalam Menggunakan $e$ Filing (Y).

\section{Hasil Uji Validitas}

\begin{tabular}{ccccc}
\hline Variabel & Pertanyaan & r-Hitung & r-Tabel & Keterangan \\
\hline & 1 & 0,787 & 0,261 & Valid \\
Persepsi & 2 & 0,852 & 0,261 & Valid \\
Kegunaan $\left(\mathrm{X}_{1}\right)$ & 3 & 0,821 & 0,261 & Valid \\
& 4 & 0,835 & 0,261 & Valid \\
& 5 & 0,798 & 0,261 & Valid \\
Persepsi & 1 & 0,818 & 0,261 & Valid \\
Kemudahan & 2 & 0,858 & 0,261 & Valid \\
$\left(\mathrm{X}_{2}\right)$ & 3 & 0,872 & 0,261 & Valid \\
& 4 & 0,737 & 0,261 & Valid \\
Keamanan dan & 5 & 0,760 & 0,261 & Valid \\
Kerahasiaan $\left(\mathrm{X}_{3}\right)$ & 1 & 0,909 & 0,261 & Valid \\
& 2 & 0,928 & 0,261 & Valid \\
Kerumitan $\left(\mathrm{X}_{4}\right)$ & 3 & 0,926 & 0,261 & Valid \\
& 1 & 0,934 & 0,261 & Valid \\
Kesiapan & 2 & 0,961 & 0,261 & Valid \\
Teknologi & 3 & 0,926 & 0,261 & Valid \\
Informasi $\left(\mathrm{X}_{5}\right)$ & 2 & 0,761 & 0,261 & Valid \\
& 3 & 0,784 & 0,261 & Valid \\
Minat & 4 & 0,846 & 0,261 & Valid \\
Menggunakan $e-$ & 5 & 0,795 & 0,261 & Valid \\
Filing $(\mathrm{Y})$ & 1 & 0,828 & 0,261 & Valid \\
\hline Sumber : & 2 & 0,882 & 0,261 & Valid \\
& 3 & 0,935 & 0,261 & Valid \\
\end{tabular}

(Sumber : Hasil Pengolahan Data Aplikasi SPSS, 2018)

Berdasarkan data yang sudah diolah, bisa dilihat, nilai $r$ tabel dengan $n=100$ dan pada signifikansi 0,01 adalah sebesar 0,261 maka dapat disimpulkan bahwa hubungan antara 
pertanyaan dari variabel $\mathrm{X}_{1}, \mathrm{X}_{2}, \mathrm{X}_{3}, \mathrm{X}_{4}, \mathrm{X}_{5}$ dan $\mathrm{Y}$, adalah valid, karena nilai semua hubungan pertanyaan lebih dari 0,261 .

\section{B. Uji Reliabilitas}

Hasil pengujian reliabilitas atas variabel Persepsi Kegunaan, Persepsi Kemudahan, Keamanan dan Kerahasiaan, Kerumitan, Kesiapan Teknologi Informasi dan Minat Wajib Pajak Orang Pribadi Dalam Menggunakan e-Filing dengan menggunakan Cronbach Alpha dapat dilihat sebagai berikut:

\section{Hasil Uji Reliabilitas}

\begin{tabular}{lc}
\hline \multicolumn{1}{c}{ Variable } & Cronbach's Alpha \\
\hline Minat Menggunakan $e$-Filing $(\mathrm{Y})$ & 0.898 \\
Persepsi Kegunaan $\left(\mathrm{X}_{1}\right)$ & 0.876 \\
Persepsi Kemudahan $\left(\mathrm{X}_{2}\right)$ & 0.871 \\
Keamanan dan Kerahasiaan $\left(\mathrm{X}_{3}\right)$ & 0.911 \\
Kerumitan $\left(\mathrm{X}_{4}\right)$ & 0.934 \\
Kesiapan Teknologi Informasi $\left(\mathrm{X}_{5}\right)$ & 0.875 \\
\hline
\end{tabular}

(Sumber : Hasil Pengolahan Data Aplikasi SPSS, 2018)

Berdasarkan hasil Cronbach's Alpha, maka dapat disimpulkan bahwa instrumen minat wajib pajak orang pribadi dalam menggunakan $e$-Filing baik atau reliabel. Karena nilai tersebut lebih tinggi dari $0,600(0,898>0,600)$.

\subsubsection{Uji Asumsi Klasik}

A. Uji Normalitas

Hasil Uji Normalitas Kolmogorov-Smirnov

\begin{tabular}{llr}
\hline & & \multicolumn{2}{c}{$\begin{array}{c}\text { Unstandardized } \\
\text { Residual }\end{array}$} \\
\hline $\mathrm{N}$ & & 100 \\
Normal Parameters & Mean & 0.0000000 \\
& Std. Deviation & 0.92461797 \\
Most Extreme Differences & Absolute & 0.073 \\
& Positive & .067 \\
Kolmogorov-Smirnov Z & Negative & -0.073 \\
Asymp. Sig. (2-tailed) & & 0.732 \\
\hline
\end{tabular}

a. Test distribution is Normal.

b. Calculated from data.

(Sumber : Hasil Pengolahan Data Aplikasi SPSS, 2018)

Berdasarkan hasil uji normalitas diperoleh nilai signifikansi sebesar 0,657 (Asymp.

Sig. (2-tailed)) dimana 0,657>0,05 maka dapat disimpulkan data berdistribusi normal. 


\subsubsection{Uji Regresi Linear Berganda}

Uji regresi linear berganda digunakan untuk mengetahui bagaimana pengaruh Persepsi Kegunaan, Persepsi Kemudahan, Keamanan dan Kerahasiaan, Kerumitan dan Kesiapan Teknologi Informasi terhadap Minat Wajib Pajak Orang Pribadi Dalam Mengggunakan $e$-Filing Sebagai Sarana Pelaporan SPT pada KPP Pratama Poso.

\begin{tabular}{|c|c|c|c|c|c|}
\hline \multicolumn{6}{|c|}{$\begin{array}{c}\text { Hasil Uji Regresi Linear Berganda } \\
\text { Coefficients }^{\mathbf{a}}\end{array}$} \\
\hline \multirow[b]{2}{*}{ Model } & \multicolumn{2}{|c|}{$\begin{array}{l}\text { Unstandardized } \\
\text { Coefficients }\end{array}$} & \multirow{2}{*}{$\begin{array}{c}\text { Standardized } \\
\text { Coefficients } \\
\text { Beta } \\
\end{array}$} & \multirow[b]{2}{*}{$\mathbf{t}$} & \multirow[b]{2}{*}{ Sig. } \\
\hline & B & Std. Error & & & \\
\hline 1 (Constant) & 0.718 & 1.168 & & .615 & 0.540 \\
\hline Persepsi Kegunaan & 0.139 & 0.052 & 0.157 & 2.668 & 0.009 \\
\hline Persepsi Kemudahan & 0.152 & 0.052 & 0.170 & 2.907 & 0.005 \\
\hline Keamanan dan Kerahasiaan & 0.257 & 0.065 & 0.258 & 3.955 & 0.000 \\
\hline Kerumitan & -0.302 & 0.043 & -0.358 & -7.106 & 0.000 \\
\hline Kesiapan Teknologi Informasi & 0.188 & 0.042 & 0.201 & 4.458 & 0.000 \\
\hline
\end{tabular}

a. Dependent Variable: MINAT MENGGUNAKAN E-FILING

(Sumber : Hasil Pengolahan Data Aplikasi SPSS, 2018)

Dari tabel 4.20 dapat diperoleh persamaan regresi linier berganda sebagai berikut:

$\mathrm{Y}=0,718+0,139 \mathrm{X}_{1}+0,152 \mathrm{X}_{2}+0,257 \mathrm{X}_{3}-0,302 \mathrm{X}_{4}+0,188 \mathrm{X}_{5}+\mathrm{e}$

Keterangan:

$\mathrm{Y} \quad$ : Minat Menggunakan -Filing

$\mathrm{X}_{1}$ : Persepsi Kegunaan

$\mathrm{X}_{2}$ : Persepsi Kemudahan

$\mathrm{X}_{3}$ : Keamanan dam Kerahasiaan

$\mathrm{X}_{4}$ : Kerumitan

$\mathrm{X}_{5}$ : Kesiapan Teknologi Informasi

$\alpha$ : Konstanta

$\beta \quad$ : Koefisien regresi

e : Standart error berikut:

Hasil persamaan regresi ini secara keseluruhan menunjukkan hasil interpretasi sebagai

1. Konstanta $(\alpha)$ sebesar 0,718 artinya bahwa jika tidak terdapat nilai Persepsi Kegunaan $\left(\mathrm{X}_{1}\right)$, Persepsi Kemudahan $\left(\mathrm{X}_{2}\right)$, Keamanan dan Kerahasiaan $\left(\mathrm{X}_{3}\right)$, Kerumitan $\left(\mathrm{X}_{4}\right)$, Kesiapan Teknologi Informasi $\left(\mathrm{X}_{5}\right)$ atau sama dengan nol maka Minat Menggunakan $e$-Filing (Y) nilainya adalah 0,718 .

2. Koefisien regresi $\left(\beta_{1}\right)$ untuk persepsi kegunaan sebesar 0,139 artinya jika variabel lainnya tetap dan persepsi kegunaan mengalami kenaikan satu satuan konstan maka minat menggunakan $e$-Filing akan mengalami pertambahan sebesar 0,139 . Koefisien bernilai positif artinya terjadi hubungan searah antara persepsi kegunaan dan minat menggunakan e-Filing, semakin tinggi persepsi kegunaan maka minat wajib pajak untuk menggunakan $e$-Filing akan semakin bertambah.

3. Koefisien regresi $\left(\beta_{2}\right)$ untuk persepsi kemudahan sebesar 0,152 artinya jika variabel lainnya tetap dan persepsi kegunaan mengalami kenaikan satu satuan konstan maka minat menggunakan $e$-Filing akan mengalami pertambahan sebesar 0,152. Koefisien bernilai positif artinya terjadi hubungan searah antara persepsi kemudahan dan minat menggunakan $e$-Filing, semakin tinggi persepsi kemudahan maka minat wajib pajak untuk menggunakan $e$-Filing akan semakin bertambah. 
4. Koefisien regresi $\left(\beta_{3}\right)$ untuk keamanan dan kerahasiaan sebesar 0,257 artinya jika variabel lainnya tetap sedangkan keamanan dan kerahasiaan mengalami kenaikan satu satuan konstan maka minat menggunakan e-Filing akan mengalami pertambahan sebesar 0,257. Koefisien bernilai positif artinya terjadi hubungan searah antara keamanan dan kerahasiaan berserta minat menggunakan $e$-Filing, semakin tinggi keamanan dan kerhasiaan maka minat wajib pajak untuk menggunakan $e$-Filing akan semakin bertambah.

5. Koefisien regresi $\left(\beta_{4}\right)$ untuk kerumitan sebesar $(-0,302)$ artinya jika variabel lainnya tetap dan kerumitan mengalami kenaikan satu satuan konstan maka minat menggunakan e-Filing akan mengalami penurunan sebesar $(-0,302)$. Koefisien bernilai negatif artinya terjadi hubungan berlawanan arah antara kerumitan dan minat menggunakan e-Filing, semakin tinggi kerumitan maka minat wajib pajak untuk menggunakan $e$-Filing akan semakin berkurang.

6. Koefisien regresi $\left(\beta_{5}\right)$ untuk kesiapan teknologi informasi sebesar 0,188 artinya jika variabel lainnya tetap dan kesiapan teknologi informasi mengalami kenaikan satu satuan konstan maka minat menggunakan e-Filing akan mengalami pertambahan sebesar 0,188. Koefisien bernilai positif artinya terjadi hubungan searah antara kesiapan teknologi informasi dan minat menggunakan e-Filing, semakin tinggi kesiapan teknologi informasi maka minat wajib pajak untuk menggunakan $e$-Filing akan semakin bertambah.

\subsubsection{Uji Koefisien Determinasi $\left(\mathbf{R}^{2}\right)$}

Hasil koefisien determinasi $\left(\mathrm{R}^{2}\right)$ akan dijelaskan dalam pembahasan berikut ini.

\section{Hasil Koefisien Determinasi $\left(\mathbf{R}^{2}\right)$}

\begin{tabular}{clrrr}
\hline Model & R & R Square & Adjusted R Square & Std. Error of the Estimate \\
\hline 1 & $0.935^{\mathrm{a}}$ & 0.874 & 0.868 & 0.949 \\
\hline
\end{tabular}

a. Predictors: (Constant), KESIAPAN TEKNOLOGI INFORMASI, KERUMITAN, PERSEPSI KEGUNAAN, PERSEPSI KEMUDAHAN, KEAMANAN DAN KERAHASIAAN

(Sumber : Hasil Pengolahan Data Aplikasi SPSS, 2018)

Menunjukan bahwa angka adjusted $R$ square adalah 0,868 . Hal ini berarti dari $100 \%$ minat wajib pajak, terdapat $86,8 \%$ minat wajib pajak orang pribadi yang terdaftar di KPP Pratama Poso dalam menggunakan e-Filing dipengaruhi oleh variabel persepsi kegunaan, persepsi kemudahan, keamanan dan kerahasiaan, kerumitan dan kesiapan teknologi informasi.

\subsubsection{Uji Hipotesis}

A. Uji t (Uji Parsial)

Uji t diilakukan untuk menguji signifikansi dari pengaruh masing-masing variabel independen terhadap variabel dependen. 


\begin{tabular}{|c|c|c|c|c|c|}
\hline \multicolumn{6}{|c|}{ Hasil Uji t (Uji Parsial) } \\
\hline \multirow[b]{2}{*}{ Model } & \multicolumn{2}{|c|}{$\begin{array}{c}\text { Unstandardized } \\
\text { Coefficients }\end{array}$} & \multirow{2}{*}{$\begin{array}{c}\begin{array}{c}\text { Standardized } \\
\text { Coefficients }\end{array} \\
\text { Beta } \\
\end{array}$} & \multirow[b]{2}{*}{$\mathbf{t}$} & \multirow[b]{2}{*}{ Sig. } \\
\hline & B & Std. Error & & & \\
\hline 1 (Constant) & 0.718 & 1.168 & & .615 & 0.540 \\
\hline Persepsi Kegunaan & 0.139 & 0.052 & 0.157 & 2.668 & 0.009 \\
\hline Persepsi Kemudahan & 0.152 & 0.052 & 0.170 & 2.907 & 0.005 \\
\hline Keamanan dan Kerahasiaan & 0.257 & 0.065 & 0.258 & 3.955 & 0.000 \\
\hline Kerumitan & -0.302 & 0.043 & -0.358 & -7.106 & 0.000 \\
\hline Kesiapan Teknologi Informasi & 0.188 & 0.042 & 0.201 & 4.458 & 0.000 \\
\hline
\end{tabular}

a. Dependent Variable: Minat Menggunakan E-Filing

(Sumber : Hasil Pengolahan Data Aplikasi SPSS, 2018)

Berdasarkan hasil analisis regresi secara parsial, maka diperoleh persepsi kegunaan memiliki nilai t-hitung sebesar 2,668 > 1,985 dan nilai signifikansi 0,009 < 0,05, dimana $\mathrm{Ha}_{1}$ diterima dan $\mathrm{Ho}_{1}$ ditolak artinya persepsi kegunaan berpengaruh signifikan (positif) terhadap minat menggunakan e-Filing. Persepsi kemudahan memiliki nilai t-hitung sebesar 2,907 > 1,985 dan nilai signifikansi $0,005<0,05$, dimana $\mathrm{Ha}_{2}$ diterima dan $\mathrm{Ho}_{2}$ ditolak artinya persepsi kemudahan berpengaruh signifikan (positif) terhadap minat menggunakan $e$-Filing. Keamanan dan kerahasiaan memiliki nilai t-hitung sebesar 3,955 >1,985 dan nilai signifikansi $0,000<0,05$, dimana $\mathrm{Ha}_{3}$ diterima dan $\mathrm{Ho}_{3}$ ditolak artinya keamanan dan kerahasiaan berpengaruh signifikan (positif) terhadap minat menggunakan $e$-Filing. Kerumitan memiliki nilai t-hitung sebesar 7,106 > 1,985 dan nilai signifikansi 0,000 < 0,05, dimana $\mathrm{Ha}_{4}$ diterima dan $\mathrm{Ho}_{4}$ ditolak artinya kerumitan berpengaruh signifikan (negatif) terhadap minat menggunakan $e$-Filing. Kesiapan teknologi informasi memiliki nilai t-hitung sebesar 4,458 > 1,985 dan nilai signifikansi $0,000<0,05$, dimana $\mathrm{Ha}_{5}$ diterima dan $\mathrm{Ho}_{5}$ ditolak artinya kesiapan teknologi informasi berpengaruh signifikan (positif) terhadap minat menggunakan $e$-Filing.

B. Uji F (Uji Simultan)

Uji F diilakukan untuk menguji signifikansi dari pengaruh semua variabel independen terhadap variabel dependen.

\begin{tabular}{|c|c|c|c|c|c|c|}
\hline \multicolumn{7}{|c|}{$\begin{array}{c}\text { Uji F (Uji Simultan) } \\
\text { ANOVA }^{\text {a }}\end{array}$} \\
\hline & Model & $\begin{array}{l}\text { Sum of } \\
\text { Squares }\end{array}$ & Df & Mean Square & $\mathbf{F}$ & Sig. \\
\hline 1 & Regression & 588.673 & 5 & 117.735 & 130.759 & $0.000^{b}$ \\
\hline & Residual & 84.637 & 94 & 0.900 & & \\
\hline & Total & 673.310 & 99 & & & \\
\hline
\end{tabular}

a. Dependent Variable: Minat Menggunakan E-Filing

b. Predictors: (Constant), Kesiapan Teknologi Informasi, Kerumitan, Persepsi Kegunaan, Persepsi Kemudahan, Keamanan dan Kerahasiaan

(Sumber : Hasil Pengolahan Data Aplikasi SPSS, 2018)

Berdasarkan hasil analisis regresi secara simultan, maka diperoleh nilai F-hitung sebesar 130,759 > 2,200 dan nilai signifikansi 0,000 < 0,05, dimana $\mathrm{Ha}_{6}$ diterima dan $\mathrm{Ho}_{6}$ ditolak artinya persepsi kegunaan, persepsi kemudahan, keamanan dan kerahasiaan, kerumitan, dan kesiapan teknologi informasi berpengaruh signifikan terhadap minat menggunakan $e$-Filing. 


\subsection{Pembahasan}

A. Pengaruh Persepsi Kegunaan (Perceived Usefulness), Terhadap Minat Wajib Pajak Dalam Menggunakan $e$-Filing.

Hasil pengujian hipotesis variabel persepsi kegunaan menunjukan nilai t hitung sebesar 2,668 dan tingkat signifikansi 0,009. Nilai signifikansi lebih kecil dari 0,05. Dengan demikian maka dapat diketahui bahwa $\mathrm{Ha}_{1}$ diterima dan $\mathrm{Ho}_{1}$ ditolak. Hal ini berarti bahwa persepsi kegunaan berpengaruh positif terhadap minat wajib pajak orang pribadi yang terdaftar di KPP Pratama Poso dalam menggunakan $e$-Filing.

B. Pengaruh Persepsi Kemudahan (Perceived Ease Of Use), Terhadap Minat Wajib Pajak Dalam Menggunakan $\boldsymbol{e}$-Filing.

Hasil pengujian hipotesis variabel persepsi kemudahaan menunjukan nilai t hitung sebesar 2,907 dan tingkat signifikansi 0,005. Nilai signifikansi lebih kecil dari 0,05. Dengan demikian maka dapat diketahui bahwa $\mathrm{Ha}_{2}$ diterima dan $\mathrm{Ho}_{2}$ ditolak. Hal ini berarti bahwa persepsi kemudahan berpengaruh positif terhadap minat wajib pajak orang pribadi yang terdaftar di KPP Pratama Poso dalam menggunakan e-Filing.

C. Pengaruh Keamanan dan Kerahasiaan (Security And Privacy), Terhadap Minat Wajib Pajak Dalam Menggunakan $e$-Filing.

Hasil pengujian hipotesis variabel keamanan dan kerahasiaan menunjukan nilai $\mathrm{t}$ hitung sebesar 3,955 dan tingkat signifikansi 0,000. Nilai signifikansi lebih kecil dari 0,05. Dengan demikian maka dapat diketahui bahwa $\mathrm{Ha}_{3}$ diterima dan $\mathrm{Ho}_{3}$ ditolak. Hal ini berarti bahwa keamanan dan kerhasiaan berpengaruh positif terhadap minat wajib pajak orang pribadi yang terdaftar di KPP Pratama Poso dalam menggunakan $e$-Filing.

D. Pengaruh Kerumitan (Complexity), Terhadap Minat Wajib Pajak Dalam Menggunakan $\boldsymbol{e}$-Filing.

Hasil pengujian hipotesis variabel kerumitan menunjukan nilai t hitung sebesar 7,106 dan tingkat signifikansi 0,000. Nilai signifikansi lebih kecil dari 0,05. Dengan demikian maka dapat diketahui bahwa $\mathrm{Ha}_{4}$ diterima dan $\mathrm{Ho}_{4}$ ditolak. Hal ini berarti bahwa kerumitan berpengaruh negatif terhadap minat wajib pajak orang pribadi yang terdaftar di KPP Pratama Poso dalam menggunakan $e$-Filing.

E. Pengaruh Kesiapan Teknologi Informasi Wajib Pajak (Readiness Technology Taxpayers Information) terhadap Minat Wajib Pajak dalam Penggunaan $e$ Filing.

Hasil pengujian hipotesis variabel kesiapan teknologi informasi wajib pajak menunjukan nilai t hitung sebesar 4,458 dan tingkat signifikansi 0,000 . Nilai signifikansi lebih kecil dari 0,05. Dengan demikian maka dapat diketahui bahwa $\mathrm{Ha}_{5}$ diterima dan $\mathrm{Ho}_{5}$ ditolak. Hal ini berarti bahwa kesiapan teknologi informasi wajib pajak berpengaruh positif terhadap minat wajib pajak orang pribadi yang terdaftar di KPP Pratama Poso dalam menggunakan $e$-Filing.

F. Pengaruh Pengaruh Persepsi Kegunaan (Perceived Ease Of Use), Persepsi

Kemudahan (Perceived Ease Of Use), Keamanan dan Kerahasiaan (Security And Privacy), Kerumitan (Complexity), Kesiapan Teknologi Informasi (Readiness Technology Taxpayers Information) berpengaruh terhadap Minat Wajib Pajak Orang Pribadi dalam Menggunakan e-Filing.

Hasil pengujian dari uji simultan (uji F) menunjukan nilai F-hitung sebesar 130,759 dan nilai signifikansi sebesar 0,000. F-hitung lebih besar dari F-tabel, yaitu 130,759>2,200 dan nilai signifikansi lebih kecil dari $\alpha(0,05)$. Hal ini berarti bahwa persepsi kegunaan, persepsi kemudahan, keamanan dan kerhasiaan, kerumitan, dan kesiapan teknologi informasi berpengaruh signifikan terhadap minat menggunakan $e$-Filing, karena F-hitung $>$ F-tabel dan tingkat signifikansi $<0,05$, dengan demikian $\mathrm{Ha}_{6}$ diterima dan $\mathrm{Ho}_{6}$ ditolak. 


\section{KESIMPULAN DAN SARAN}

\subsection{Kesimpulan}

Berdasarkan hasil penelitian yang ada, maka dapat diambil beberap kesimpulan sebagai berikut:

1. Persepsi Persepsi Kegunaan (Perceived Usefulness) berpengaruh positif terhadap Minat Wajib Pajak Orang Pribadi Dalam Menggunakan e-Filing, dengan nilai t-hitung sebesar 2,668 > 1,985 dan nilai signifikansi 0,009 $<0,05$ serta mempunyai hubungan positif terhadap minat menggunakan e-Filing dengan nilai koefisien regresi $\left(\beta_{1}\right)$ sebesar 0,139 .

2. Persepsi Kemudahan (Perceived Ease Of Use) berpengaruh positif terhadap Minat Wajib Pajak Orang Pribadi Dalam Menggunakan e-Filing, dengan nilai t-hitung sebesar 2,907 > 1,985 dan nilai signifikansi $0,005<0,05$ serta memiliki hubungan positif terhadap minat menggunakan e-Filing dengan nilai koefisien regresi $\left(\beta_{2}\right)$ sebesar 0,152.

3. Keamanan dan Kerahasiaan (Security And Privacy) berpengaruh positif terhadap Minat Wajib Pajak Orang Pribadi Dalam Menggunakan e-Filing, dengan nilai t-hitung sebesar 3,955 > 1,985 dan nilai signifikansi $0,000<0,05$ serta memiliki hubungan positif terhadap minat menggunakan e-Filing dengan nilai koefisien regresi $\left(\beta_{3}\right)$ sebesar 0,257.

4. Kerumitan (Complexity) berpengaruh negatif terhadap Minat Wajib Pajak Orang Pribadi Dalam Menggunakan $e$-Filing, dengan nilai t-hitung sebesar 7,106 > 1,985 dan nilai signifikansi $0,000<0,05$ serta memiliki hubungan negatif terhadap minat menggunakan $e$-Filing dengan nilai koefisien regresi $\left(\beta_{4}\right)$ sebesar $(-0,302)$.

5. Kesiapan Teknologi Informasi Wajib Pajak (readiness technology taxpayers information) berpengaruh positif terhadap Minat Wajib Pajak Orang Pribadi Dalam Menggunakan $e$-Filing, dengan nilai t-hitung sebesar 4,458>1,985 dan nilai signifikansi $0,000<0,05$ serta memiliki hubungan positif terhadap minat menggunakan $e$-Filing dengan nilai koefisien regresi $\left(\beta_{5}\right)$ sebesar 0,188.

6. Persepsi Kegunaan, Persepsi Kemudahan, Keamanan dan Kerahasiaan, Kerumitan, Kesiapan Teknologi Informasi berpengaruh signifikan terhadap Minat Wajib Pajak Orang Pribadi dalam Menggunakan e-Filing, dengan nilai F-hitung sebesar 130,735 > 2,200 dan nilai signifikansi $0,000<0,05$ serta memiliki nilai koefisien determinasi $0,868(86,8 \%)$.

\subsection{Saran}

Adapun beberapa saran yang dapat disampaikan berdasarkan kesimpulan dari hasil penelitian ini adalah sebagai berikut:

\section{a. Bagi KPP Pratama Poso}

1. Direktorat Jendral Pajak dapat meningkatkan kualitas pelayanannya dalam memperkenalkan $e$-Filing, baik dalam media cetak maupun media elektronik.

2. Direktorat Jendral Pajak dapat meningkatkan sosialisasi-sosialisasi e-Filing agar pemanfaatan sistem $e$-Filing dapat lebih meluas dan lebih banyak digunakan oleh Wajib Pajak.

3. Penggunaan sistem e-Filing dapat lebih mudah dimengerti dan dipelajari oleh Wajib Pajak, sehingga dapat menambah minat Wajib Pajak dalam penggunaan sistem $e$ Filing.

\section{b. Peneliti Selanjutnya}

1. Penelitian selanjutnya dapat menambahkan variabel lainnya. Hal ini dilakukan agar dapat mengetahui variabel lain yang mempengaruhi penggunaan sistem e-Filing secara tepat dan sesuai, misalnya variabel ekuitas pajak. 
2. Penelitian selanjutnya dapat menambah jumlah sampel yang akan diteliti serta memperluas ruang lingkup penelitiannya. Dapat memperluas sampel misalnya wajib pajak badan yang terdaftar di KPP.

\section{DAFTAR PUSTAKA}

Ajzen, I. 2005. Attitudes, Personality and Behavior, (2nd edition). Berkshire, UK: Open University Press-McGraw Hill Education

Amoroso, Gardner. 2004. Kajian mengenai Perilaku Penggunaan an internet dalam sistem informasi dengan pendekatan Technology Acceptance Model (TAM).

Davis, F.D. 1989. Technology Acceptance Model for Empirically Testing New End-User Information Systems Theory and Results; Unpublished Doctoral Dissertation MIT.

Ekamaulana, Faisal Afiff. 2016. Analisis Faktor-Faktor Yang Mempengaruhi Minat Wajib Pajak Orang Pribadi Dalam Menggunakan E-filing (Studi Empiris pada Wajib Pajak Orang Pribadi di Kota Banjarmasin). Fakultas Ekonomi dan Bisnis Universitas Brawijaya.

Goodhue, D.L. and Thompson, R.L. 1995.Task-Technology Fit and Individual Performance. MIS Quarterly (19:2), pp. 213- 236.

Laihad, Risal C.Y. 2012. Pengaruh Perilaku Wajib Pajak Terhadap Penggunaan e- Filling Wajib Pajak di Kota Manado. Jurnal EMBA. ISSN 2303-1174. Vol.1 No.3 September 2013.

Sakti, Nufransa Wira. 2015. Panduan Praktis Mengurus Pajak Secara Online. Jakarta : Visimedia.

Sugiyono. 2016. Metodologi Penelitian Kuantitatif, Kualitatif, dan R\&D. Bandung: CV Alfabeta.

Tania, Inka. 2016. Faktor-Faktor yang Mempengaruhi Minat Wajib Pajak Dalam Menggunakan Fasilitas E-filing (Studi Kasus pada Kantor Pelayanan Pajak Pratama Kepanjen). Skripsi. Malang : Fakultas Ekonomi dan Bisnis Universitas Brawijaya.

Venkatesh, V. dan Davis, F.D. 2000. A Theoretical Extension of the Technology Acceptance Model: Four Longitudinal Field Studies. Management Science, 46 (2), pp. 186-204

Wibisono, L.T. dan Toly, Agus Arianto 2014. Analisis Faktor-Faktor Yang Mempengatuhi Minat Wajib Pajak Dalam Penggunaan E-Filing Di Surabaya. Jurnal Tax \& Accounting Review, Vol 4. No.1, 2014. 